\title{
Sertraline Induced Excessive Yawning
}

\author{
Daniela Petrić ${ }^{1}$, Marija Vučić Peitl ${ }^{1}$, Joško Prološčić ${ }^{1}$, \\ Vjekoslav Peit| 2,3 \\ ${ }^{1}$ Department of Psychiatry of the University Hospital Centre Rijeka, Croatia, ${ }^{2}$ Depart- \\ ment of psychiatry of the University Hospital Centre Sestre milosrdnice, ${ }^{3}$ Catholic Uni- \\ versity of Croatia, Zagreb, Croatia
}

\begin{abstract}
Background: Even though there is a growing interest in the neurophysiology of yawning, it still remains somewhat of a scientific mystery due to the fact that we still do not know the exact mechanisms behind it. Apart from physiological yawning, abnormal and excessive yawning has been observed in numerous pathologies, mostly in neurological and psychiatric disorders, as well as side effects of various medicaments. Subject: We will present the case of a 42 year old woman who developed excessive yawning as a side effect of treatment with sertraline. Discussion: Although we still do not know the exact mechanism behind yawning, several neurotransmitters and neuropeptides are thought to be involved in the neurophysiology of yawning, especially serotonin and dopamine. Subsequently, excessive yawning has been observed in some patients treated with the majority of novel serotonergic antidepressants. Conclusion: Excessive yawning requires the same clinical attention as other side effects of antidepressant treatment and therefore should be carefully considered and managed. Intolerance to antidepressant treatment is a significant cause of treatment failure and that is why psychiatrists should keep in mind that sertraline could cause such a disabling side effect as excessive yawning.
\end{abstract}

Key words: case report, sertraline, yawning, side effect

Copyright (C) 2019 KBCSM, Zagreb

e-mail: alcoholism.kbcsm@gmail.com•www.http://apr.kbcsm.hr

\section{Introduction}

Yawning is a common physiological event that occurs in humans, as well as in animals. It is not considered to be a simple reflex but rather a stereotyped event with unknown physiological functions. It is interesting to observe that fifty percent of people yawn

Correspondence to: Daniela Petrić, M.D., PhD.

Cambierieva 17/7, Rijeka, 51000, Croatia

E-mail: daniela.petric@me.com

Tel: 051-658-334 , Fax: 051-333-323 after seeing someone else yawn. Even hearing or reading about yawning may induce another person to yawn. It is speculated that contagious yawning might be an innate action that recognizes a particular behavioral state [1]. On another note, abnormal yawning has been observed in numerous pathologies (neurological, psychiatric, iatrogenic, and infectious diseases) [2]).

Although there is a growing interest in the neurophysiology of yawning, it remains somewhat of a scientific mystery due to the 
fact that we still do not know the exact mechanisms behind it. When discussing theories, the most common is that yawning compensates oxygen deficiency in the blood [1]. Other theories consider yawning to be a thermoregulative mechanism that lowers brain temperature [1, 3], especially considering the fact that yawning has many physiological consequences that are consistent with those required for the regulation of brain temperature. It has been observed that several mental disorders affect brain thermoregulation, including depressive and manic disorder. More specifically, brain temperature may rise in depressive individuals and lower in patients suffering from mania. Furthermore, the majority of therapeutic strategies against mania are hypothermic, while those against depressive disorders are thermogenic [1]. Several neurotransmitters and neuropeptides and their complex interplay represent another major point of interest in the neurophysiology of yawning [4].

Many medicaments, including psychopharmacs, can also cause severe and pathological yawning. Yawning has been observed in some patients treated with the majority of novel serotonergic antidepressants, like escitalopram [1], paroxetine [5], venlafaxine [6, 7], duloxetine [8], fluoxetine [9, 10], and sertraline $[10,11]$, as well as with tricyclic antidepressants like clomipramine and desipramine [10].

\section{Case report}

We will present the case of a 42 year old woman, mother of two children, who began treatment for a moderately severe depressive episode. Her psychic disturbances became apparent when she was still in high school, when she sought help from the school's ther- apist. She had been feeling "depressive" for years, but during the last year and a half she became increasingly apathetic, indisposed, emotionally unstable and cried a lot. Based on these symptoms her general practitioner introduced the antidepressant paroxetine to the treatment, but prolactine levels increased soon afterwards [912.1] and led to the development of hyperprolactinemia, which in turn led to decreased libido and absence of orgasm. Understandably, paroxetine was soon discontinued from treatment and she decided to seek psychiatric help.

In January 2012 she sought psychiatric help for the first time due to a three week long deterioration of her psychological health which manifested as lowered mood, apathy and diminished energy and volition. The assessment of her psychological status showed a well kempt patient, without orientation and consciousness disturbances, spontaneous in contact although needing occasional assistance, but crying during the whole interview. Psychomotor agitation was present. Her complexion was pale and her general mood was low. There were no formal thought disturbances and the thought content was filled with depressive ideas from moral and health areas, her attention was hypovigilant and she presented hypertenacity of attention without sensory delusions, with low vital dynamisms but no suicidal ideation. Mnestic functions and intelligence seemed unimpaired. Family history was negative for psychiatric disorders. Treatment was started with Sertraline at 25 mg daily during the first two days, after which the dose was increased to 50 daily during the next three days and after the initial five days the dose was increased to $75 \mathrm{mg}$ daily. Alprazolam at $0.25 \mathrm{mg}$ was also introduced to treatment with a suggestion to use it only when really needed rather than regularly. 
At the follow-up psychiatric examination after two weeks the patient stated that couple of days after sertraline introduction she started to yawn excessively, approximately 2 to 3 times after $25 \mathrm{mg}$ and 3 to 4 times after $50 \mathrm{mg}$. She also complained that her "temporomandibular joint is unable to close her mouth". Sertraline was then discontinued, with her psychiatric status largely unchanged and disturbances still present. Tianeptine was then introduced at $12.5 \mathrm{mg}$ daily during the first three days, after which the dose was increased to $25 \mathrm{mg}$ daily during the following three days and from then onwards to $37.5 \mathrm{mg}$ daily, along with alprazolam when needed. We chose to slowly and cautiously adjust the dosage of the newly introduced antidepressant because the patient had developed side effects while treated with two different antidepressants.

At the control psychiatric examination after two weeks there were no apparent side effects of tianeptine treatment and the patient's psychical state improved significantly.

\section{Discussion}

Although we still do not know the exact mechanism behind yawning, we have already mentioned that several neurotransmitters and neuropeptides are thought to be involved in the neurophysiology of yawning, especially dopamine, serotonin, acetylcholine, nitric oxide, excitatory amino acids, oxytocin, opioid peptides, adrenocorticotropin, $\alpha$-melanocyte stimulating hormone and related peptides. Involvement of serotonin in the expression of yawning is based on pharmacological experiments showing that drugs which act selectively on the 5-HT2C receptor subtype are extremely effective in inducing yawning when given systemically in rats, monkeys and humans [4].
We presented the case of a female patient who developed excessive yawning when on small doses of sertraline, and the increased dose lead to more frequent yawning that was bothersome for the patient. This is in accordance with several other case reports on sertraline treatment. Reviewing the available literature we found a report of a patient who had 75 to 100 yawning episodes daily following a 1 to 2 week treatment with $50 \mathrm{mg}$ of sertraline [10].

In this case, as well as in those already published, dose lowering and eventual discontinuation of sertraline lead to cessation of yawning episodes. Introduction of another antidepressant to the treatment did not cause the same side effect, mainly because medication with other pharmacologic properties was used [10].

Although described, sertraline induced excessive yawning is extremely rare and we still do not know why it occurs. Beside the already mentioned serotonin mechanism, one possible explanation would be the involvement of dopamine along with serotonin [4]. As it is known, sertraline acts as a dopamine reuptake inhibitor, although in much higher doses than those that inhibit serotonin reuptake. As dopamine is also thought to have a significant role in the physiology of yawning, we can only speculate on the possible mechanism of development of yawning in this case. Further scientific research is necessary as all current theories on yawning are unable to completely clarify its physiology.

\section{Conclusion}

Excessive yawning requires the same clinical attention as the other side effects of antidepressant treatment and therefore should be carefully considered and managed. Intol- 
erance to antidepressant treatment is a significant cause of treatment failure and that is why psychiatrists should keep in mind that sertraline might cause such a disabling side effect as excessive yawning.

\section{References}

1. Thompson SB: The dawn of the yawn: Is yawning a warning? Linking neurological disorders. Med Hypotheses. 2010;75:630-633.

2. Gutierrez-Alvarez AM: Do your patients suffer from excessive yawning? Acta Psychiatr Scand. 2007;115:80-82.

3. Gallup AC, Gallup GG: Venlafaxine-induced excessive yawning: A thermoregulatory connection. Progress Neuro-Psychopharmacol Biol Psychiatry. 2009;33:747.

4. Argiolas A, Melis MR: The neuropharmacology of yawning. Eur J Pharmacol. 1998;343:1-16.

5. Harada KI: Paroxetine-induced excessive yawning. Psychiatry Clin Neurosci. 2006;60:260.

6. Chen $\mathrm{CH}$, Lu ML: Venlafaxine-induced excessive yawning. Progress Neuro-Psychopharmacol Biol Psychiatry. 2009;33:156-7.

\section{Acknowledgments}

None.

\section{Conflict of interest}

None to declare.
7. Nayak R, Bhogale GS, Patil NM: Venlafaxine and excessive yawning: is there any link? J Neuropsychiatry Clin Neurosci. 2011;23:56-7.

8. De Las Coevas C, Sanz EJ: Duloyetine-induced excessive disturbing and disabiling yawning. J Clin Psychopharmacol. 2007; 27:106-7.

9. Cohen AJ: Fluoxetine-induced yawning and anorgasmia reversed by cyproheptadine treatment. J Clin Psychiatry. 1992;53:174.

10. Beale MD, Murphree TM: Excessive yawning and SSRI therapy. Int J Neuropsychopharmacol. 2000;3:275-26.

11. Degner D, Schmidt B, Ruther E, Grohmann R: Excessive yawning under treatment with sertraline and venlafaxine. Psychopharmakotherapie. 2006;13:255-27.

\section{Prekomjerno zijevanje uzrokovano Sertralinom}

Sažetak - Pozadina: lako postoji sve veći znanstveni interes za istraživanjem neurofiziologije zijevanja, ono i dalje predstavlja znanstvenu zagonetku jer je točan mehanizam nastanka još uvijek nepoznat. Abnormalno i prekomjerno zijevanje se javlja u brojnih bolesti i poremećaja, no posebice u psihijatrijskih i neuroloških poremećaja, te kao nuspojava raznih medikamenata. Ispitanici: Prikazat ćemo slučaj četrdesetdvogodišnje žene kod koje je došlo do razvoja prekomjernog zijevanja kao nuspojave liječenja sertralinom. Rasprava: lako su točni mehanizmi nastanka zijevanja još uvijek nepoznati, za nekoliko neurotransmitera i neuropeptida se smatra da igraju važnu ulogu u neurofiziologiji zijevanja, posebice monoamini serotonin i dopamin. U skladu s time, prekomjerno zijevanje je zabilježeno kao nuspojava u određenom broju bolesnika liječenih većinom novijih serotonergički aktivnih antidepresiva. Zaključak: Sam fenomen zijevanja, a posebice zijevanje kao posljedica nuspojave liječenja antidepresivima, treba dobiti na značenju kao i druge nuspojave, te može biti predmetom proučavanja kako patofiziologije bolesti, tako i djelovanja drugih lijekova u ljudi.

Ključne riječi: prekomjerno zijevanje, sertralin, nuspojava, prikaz slučaja 